\title{
DIFFERENTIATED LEARNING IN THE FOREIGN LANGUAGE CLASSES
}

\author{
Georgeta OBILIŞTEANU, Brânduşa-Oana NICULESCU \\ "Nicolae Bălcescu” Land Forces Academy, Sibiu, Romania \\ pusa_obi@hotmail.com, branducosma@yahoo.com
}

\begin{abstract}
One of the tendencies manifested in the modernization of education is related to the flexibility of instruction aiming to ensure the development of the capacities and aptitudes of each student in accordance with his/her own possibilities and interests. The means of acquiring knowledge and of constantly and creatively applying it into practice should be made available to the students through the teaching-learning-evaluating process. Differentiated instruction can be identified neither with the strategies used, nor with a certain pattern of teaching. It goes beyond that, being a view of teaching and learning that starts from taking into consideration the students' interests, needs and styles of learning. Teachers have to adapt the whole educational process to the diversity of individuals, avoiding social marginalization or exclusion. The pedagogy and psychology of education is confronted with the complex issue of differentiating and individualizing instruction, which is the indispensable assumption in ensuring each student's success in achieving the highest possible intellectual performance. The teacher's important role is that of designing tasks that correspond to the level of proficiency of the group of students he/she is working with.
\end{abstract}

Keywords: learning, acquisition, differentiating and individualizing instruction, intellectual performance

\section{Introduction}

The efficiency and sustainability of the process of change in education consists in creating policies, curricula and methodologies that promote differentiating and individualizing the training of students in the $21^{\text {st }}$ century education practiced in our country. The strength of such an action would be a means of solving the problem of the educational input. Therefore, the shift of focus towards the influence exerted on the living human being, rooted in a specific cultural and axiological background, could be a restoration of humanism in the didactic practice, being in accordance with the new educational theories of intelligence.

Any young student must be able to identify his/her own path of personal development resulting in developing each student's individual psychological potential, according to the information drawn from the instructional activities in school, real life etc. and in finding their own personal solutions of achieving success. This is possible only when all the components having an impact on the way students develop - teachers, students, parents, the community, the educational practice encourage the use of a wide range of didactic activities corresponding to the different levels of knowledge and skills, as well as to their needs, interests and motivations.

Individuals have different cognitive and emotional capacities of relating and accessing the various, complex and innovative pieces of information, with a view to solving the problems they are 
confronted with in real life. All educational teaching-learning-evaluating which provides students with the necessary means of acquiring the knowledge and skills specified in the syllabus, allowing them to creatively and constantly implement the theoretical acquisitions into every day practice. The important role of the teacher in the foreign language class is that of designing a variety of didactic activities, as well as a wide range of teaching and learning resources that can be adapted to the level of language he is working with.

\section{Modern educational principles}

Designing and organizing the instructional-educational activities depend on the teacher's strategic decision. This will place the students in the most appropriate position that allows them to fully develop their capabilities. Conceived as a didactic scenario with a complex structure, the strategy rules out to a large extent the institutions should promote that process of hazards, errors and undesirable events taking place in pedagogical practice. In order to achieve "a flexible interaction between the teacher's and the students' actions, it is necessary that the latter's potential should be taken into account: motivation, capacity to act in a certain way, style of learning" [1].

Managing differentiating and individualizing teaching involves bringing together all the components of the curriculum, including the interactions occurring between them. A new paradigm emerges in response to the students' interests and learning pace, according to which "teachers can differentiate the content, process and product through a range of managerial and educational strategies" [2].

The traditional educational principles as opposed to the modern ones are as follows [3]:

Table no. 1 Traditional educational principles vs. modern educational principles

\begin{tabular}{|c|c|}
\hline Traditional educational principles & Modern educational principles \\
\hline $\begin{array}{l}\text { - focus on the acquisition of } \\
\text { transmission information; }\end{array}$ & $\begin{array}{l}\text { - necessity of permanent learning is } \\
\text { underlined, with a focus on the } \\
\text { connections between the different pieces } \\
\text { of information and on the new concepts; }\end{array}$ \\
\hline learning is a product; & learning is a process; \\
\hline $\begin{array}{l}\text { - hierarchical, authoritarian structure } \\
\text { where conformity is rewarded while } \\
\text { thinking differently is discouraged; }\end{array}$ & $\begin{array}{l}\text { - teachers and students regard each } \\
\text { other as human beings rather than as } \\
\text { roles; }\end{array}$ \\
\hline $\begin{array}{l}\text { - rigid structure of instructional- } \\
\text { educational process, with compulsory } \\
\text { syllabi; }\end{array}$ & $\begin{array}{l}\text { - flexible structure of the instructional- } \\
\text { educational process, with elective } \\
\text { disciplines and alternative working } \\
\text { methods; }\end{array}$ \\
\hline $\begin{array}{l}\text { the pace of acquiring knowledge is the } \\
\text { same for all students; }\end{array}$ & $\begin{array}{l}\text { - students have different cognitive } \\
\text { capabilities, therefore individual rhythms } \\
\text { of acquiring information and skills; }\end{array}$ \\
\hline $\begin{array}{l}\text { - focus on successful performance in } \\
\text { achieving learning objectives; }\end{array}$ & $\begin{array}{l}\text { - focus on developing the students' } \\
\text { personality; }\end{array}$ \\
\hline - $\quad$ analytical thinking is aimed at; & $\begin{array}{l}\text { - combining linear with non-linear } \\
\text { (based on intuition) thinking is aimed at; }\end{array}$ \\
\hline $\begin{array}{l}\text { - learning has in view the present } \\
\text { moment, recycling information taking } \\
\text { place as a result of scientific progress; }\end{array}$ & $\begin{array}{l}\text { - learning has in view the future, } \\
\text { recycling information anticipating } \\
\text { scientific progress. }\end{array}$ \\
\hline
\end{tabular}


The overall finality of differentiated and personalized educational programmes is the adaptation of the curriculum to the specific needs and interests of the target students. In practice, the various systems of education provide various means of differentiating the content, such as:

- the system of credits: the content is divided into units corresponding to a semester, year or cycle of study; some units are compulsory, others are elective, the student having the possibility to choose which ones he/she attends; "basic training is covered through the compulsory units (the general plan), while special training through the units pertaining to the special plan, the cultural plan being responsible for enriching the cultural background" [4];

- the modular system is also an efficient way of differentiating and personalizing the content of education.

From the perspective of the designed didactic strategies, differentiation in the foreign language classes involves the use of a diverse whole set of complementary methods: conversation, particularly euristic conversation, demonstration, explanation, exercise, independent work charts.

\section{Individualizing instruction in the foreign language classes}

Differentiated instruction refers to the teaching-learning process that makes use of didactic strategies that are adapted to the students' different possibilities, their own capacities of understanding and accomplishing the tasks [5]. The teacher's important role is that of designing tasks that correspond to the level of proficiency of the group of students he/she is working with. Individualizing and exploiting various didactic activities is the only means by which the students' needs and interests are put to good use, motivating and stimulating them into achieving the full potential of their aptitudes and skills.

Since the foreign language groups are usually a heterogeneous mix, consisting of students with different levels of language mastery, the teacher has to produce not only appropriate didactic tasks, but also various teaching and learning resources that correspond to the students' level of language proficiency. The less able students should be involved in the activities taking place in class by pairing them with the more able ones or assigning them roles they are able to assume. If the tasks are too difficult, the students will lose face and feel frustrated and, if the tasks are not hard enough, they will not have a feeling of satisfaction and will not continue to take pains into solving them.

Teachers should establish a positive atmosphere in which the learning encounters are constructive and the students are constantly encouraged to deal with the tasks at hand. It is only through differentiated learning activities that take into account the students' particularities, as well as their needs and interests, that teachers can make students relate to each other and cooperate in fulfilling the didactic activities designed by them.

Within the foreign language classes of the Land Forces Academy, individualizing the students' learning activities is more than necessary, being a fundamental strategy used for adapting the teaching tasks to the various learning possibilities of students, to the specific capacities of understanding reality, to the individual rhythm of study of each and every student.

The goal of the teachers working in the military academy is that of transforming each individual student into a personality capable of creating new material and spiritual values, of understanding the complexity of the contemporary world, of finding an appropriate educational path for accomplishing a successful military career. The starting point in designing and planning lessons is the student, the stage he/she is in at a certain moment of development. There are certain specific 
aspects which characterize differentiated instruction: planning and organizing activities in accordance with the students' needs of development; focus on the students' individual characteristics; creating learning opportunities for students, adapted to their needs and interests; using pair work and group work methods of teaching; teachers' assuming new roles; a great range of didactic materials and flexibility in their use.

\section{Teacher's role in individualizing instruction}

Differentiating instruction is, in fact, a diversification in the organization of the process of education in accordance with the age and individual characteristics of students, as well as with the peculiarities of the socio-cultural conditions. The theory of differentiated instruction is based on several fundamental rights and principles:

- being different is a fundamental right;

- there are significant differences between students in terms of learning pace, wealth and depth of knowledge/ information, style of learning;

- recognizing and respecting the differences between the inborn and the acquired capacity of students provide equal chances in education;

- having equal access to education is not equivalent to 'school for all', but to school adjusted to each student's aptitudes and needs.

More than ever before, the teacher is confronted with deciding upon differentiating and personalizing his/her formative intervention, which demands he/she should develop the students' cognitive and evaluative competences that lead to their social success. "The permanent challenge of the class is nothing else but a chance of expressing his/her didactic craftsmanship" [6].

In developing the skill of speaking within the heterogeneous groups the foreign language teacher works with, the teacher should give the learners more freedom to communicate since the focus is on fluency rather than accuracy. The less able students will be allowed to produce some errors in order to gain confidence in using the language autonomously. The ability of speaking is often developed through pair work and group work activities, the teacher having the role of facilitator. The students' needs and interests must be taken into consideration in designing the communication activities (solving problems, mini-speeches, information transfer to tables and charts, playing different roles, controlled conversation) so that students are encouraged to speak about themselves and share their own life experience with mates. Integrating mini-speeches into foreign language classes, is not so easy for the teacher who "has to oversee the different steps of the project work, establish guidelines, help students to make decisions, and provide instruction in the language" [7]. Besides the communication activities, teachers should create opportunities for students to express what they want to say. Any attempts at natural language use must be encouraged even if they may not be wholly accurate. In other words, foreign language teaching should be personalized, motivating students to express their thoughts and opinions on what is of interest to them. These opportunities show them that "the language they are learning can be used to talk about something personal" [8].

In developing the skill of writing, there are some requirements that should be met by teachers so that the objectives of the learners can be achieved:

- writing exercises should match the students' level of language proficiency, both in terms of lexis and grammar patterns; in fact, they should strengthen the vocabulary and grammatical patterns the students have recently been taught to use;

- writing tasks should be brief and provided as often as possible; many fruitful exercises are quite short assignments the 
teachers devise in order to give students the chance to reinforce their vocabulary and grammar acquisitions;

- writing tasks should be relevant to the students, most often arising naturally out of the other activities in class. In order to consolidate the other aims of the syllabus, teachers should integrate the writing exercises with the didactic activities used in developing the other language skills.

In the foreign language classes, a situation is created and an activity is set in motion, but it is the students themselves who get involved and actively take part in the interactions and the learning encounters designed by teachers. There will often be several groups or pairs performing simultaneously, without the teacher's continuous supervision. For many students, the transition to undirected activity may create difficulties and tensions at first as they will not be familiarized with this responsibility. Teachers should not ignore this aspect and be prepared to wean students gradually from dependence on their own control.

\section{Conclusions}

Since today's society requires students to be able to confront a multitude of complex situations, "the traditional education based solely on the transmission of knowledge is no longer sufficient" [9].

The contemporary system of education is characterized by the students' being capable to assume the responsibility of acquiring competences and by the teachers' being organizers of learning experiences for each and every student, fighting against uniformity of learning conditions.

An educational activity is studentcentred if it simultaneously meets several requirements: it is based on the students' individual characteristics; its goal is to develop competences (major objective) and to transmit information (secondary objective); it actively involves students in planning, carrying out and evaluating it; it represents a positive learning encounter; it allows for the transfer of experience to another educational situation.

From among the many benefits of using personalized instruction, we can mention some: all the students participate in the activities taking place in class, engaging in carrying out all the tasks assigned by the teacher; each student will be involved in an activity; the teacher knows when and how to support the students who need help so that each student will manage to accomplish the didactic activity; the curricular objectives are correlated with the students' needs and interests; the educational strategies are adapted to the different learning styles, while the students' learning pace is respected and previous experience is put to good use; the gaps in knowledge and skills do not become barriers in learning and do not create major problems later on; the students are assessed and compared with themselves and with the way they evolve throughout the program of study; the teachers are more efficient since they save time in teaching by not having to review the information or organizing further tutorials for the less able students.

\section{References}

[1] MEC, UNICEF, Strategii educaţionale centrate pe elev, București, 2006, p. 99.

[2] ***, Instruirea diferenţiată, Aplicaţii ale teoriei inteligenţelor multiple, Ghid pentru formatori şi cadre didactice, MEC, Seria calitate în formare, Bucureşti, 2001, p. 34.

[3] Cucoş, Constantin, Pedagogie, Iaşi, Editura Polirom, 2014, p. 289.

[4] Instruirea diferenţiată. Aplicaţii ale teoriei inteligenţelor multiple. Ghid pentru formatori şi cadre didactice, MEC, Seria calitate în formare, Bucureşti, 2001, pp. 29-30. 
[5] Bar-Yam, Miriam, Rhoades, Kathleen, Booth Sweeney, Linda, Kaput, Jim, and Bar-Yam, Yaneer, Changes in the Teaching and Learning Process in a Complex Education System, in Complex Systems Perspectives on Education and the Education System, New England Complex Systems Institute, 2002, retrieved from http://www.necsi.edu/research/management/education/teachandlearn.html, 17th February 2016.

[6] MEC, UNICEF, Strategii educationale centrate pe elev, Idem., p. 7.

[7] Boştină-Bratu, Integrating Culture and Civilization into the Teaching of French to LowerIntermediate Students, Proceedings II of the 19th International Scientific Conference KBO, pp. 709-712, Sibiu, Romania, 13-15 June, 2013.

[8] Byrne, Donn, Teaching writing skills, England, Longman Group UK Limited, 1995, p. 30.

[9] Mihăilă-Lică, Gabriela, Fleischer, Wiegand Helmut, Palea, Lucia-Larissa, Considerations on Recruting and Retaining University Teachers, Proceedings II of the 21st International Scientific Conference KBO, pp. 328-332, Sibiu, Romania,11-13 June, 2015. 